\title{
FOLLOW-UP OF THE ANEURYSMAL SAC AFTER EXCLUSION AND BYPASS OF POPLITEAL ARTERY ANEURYSMS
}

Tais Bugs Wakassa, Patrícia Matsunaga, Erasmo Simão da Silva, Carlos A.Pinto, Paulo Kauffman, Ricardo Aun, and Pedro Puech-Leão

\begin{abstract}
Wakassa TB, Matsunaga P, da Silva ES, Pinto CAV, Kauffman P, Aun R et al. Follow-up of the aneurysmal sac after exclusion and bypass of popliteal artery aneurysms. Clinics. 2006;61(2): 107-12.

Popliteal artery aneurysms are frequent and may lead to thromboembolic events and limb loss.

PURPOSE: To evaluate clinical and ultrasonographic follow-up of patients who underwent exclusion of a popliteal artery aneurysm using the technique proposed by Edwards.

METHODS: Data of all patients who underwent surgery to repair a popliteal artery aneurysm at Hospital das Clinicas, the São Paulo University Medical School between 1996 and 2004 were reviewed. Inclusion criteria were repair with aneurysm exclusion and bypass using the technique proposed by Edwards, as well as the existence of preoperative and postoperative measurements of the aneurysmal sac.

RESULTS: Data of 16 patients who underwent 20 procedures for popliteal artery aneurysm exclusion and bypass were available to analysis. The preoperative diameter of the popliteal artery aneurysms ranged from $1.3 \mathrm{~cm}$ to $6.1 \mathrm{~cm}(\mathrm{mean}=3.1 \mathrm{~cm})$. Patients underwent duplex ultrasound scanning 1 month to 7 years after surgical repair. Follow-up of the 20 cases revealed that 10 aneurysms exhibited decreased mean transverse diameters, ranging from 0.2 to $2.3 \mathrm{~cm}$, while 7 had increased in diameter, ranging 0.3 to 3.3 $\mathrm{cm}$, and 3 remained unchanged. Flow was observed only in 5 outo f the 20 procedures, 3 of which (60\%) had increased diameters. CONCLUSION: Although exclusion is a widely accepted procedure for the repair of popliteal artery aneurysms, data in the literature and the results of this study, which did not include cases of rupture or compression, suggest that strict follow-up of patients who undergo aneurysm exclusion is necessary.
\end{abstract}

KEYWORDS: Popliteal artery aneurysm. Arterial aneurysm. Postoperative follow-up.

\section{INTRODUCTION}

Popliteal artery aneurysms are frequent and may lead to thromboembolic events and limb loss. ${ }^{1-4}$, as is the case with other limb arterial pathologies.,

In 1969, Edwards described a technique for exclusion of the aneurysmal sac by means of proximal and distal ligation and autogenous vein interposition graft. ${ }^{7}$ This technique avoids dissection of the aneurysm and reduces edema

Department of Vascular Surgery, Hospital das Clinicas, São Paulo University Medical School - São Paulo/SP, Brazil.

Email: tbugs@terra.com.br

Received for publication on December 08, 2005.

Accepted for publication on December 23, 2005. of the limb and the risk of vein or nerve lesion. However, collateral branches may be left without ligation, which may result in persistent perfusion of the excluded aneurysm. This prevents complete sac thrombosis and eventually leads to sac enlargement.

The purpose of this study was to use ultrasonographic analysis, a frequently employed tool, ${ }^{8}$ in conjunction with a clinical evaluation for the follow-up of patients who underwent exclusion of popliteal artery aneurysms using the technique proposed by Edwards.

\section{METHODS}

Data of all patients who underwent surgery to treat pop- 
liteal artery aneurysm (PAA) at HCFMUSP between 1996 and 2004 were reviewed. All patients underwent clinical follow-up and duplex ultrasound surveillance.

Patients included in the study had aneurysms repaired by exclusion and bypass using the technique proposed by Edwards.

Analysis excluded patients without preoperative ultrasound measurement of the aneurysmal sac and patients for whom postoperative measurement was impossible due to death, amputation, or loss to follow-up.

Patients returning for routine clinical follow-up were examined for signs and symptoms of compression developed after surgery: pain, paresthesia, paresis, or venous hypertension. Duplex scanning was used to measure the greatest transverse diameter of the excluded aneurysm. Color Doppler imaging was used to evaluate intrasac flow. The interval from surgical repair to control duplex scanning was variable, as shown in Figure 1.

\section{Follow-up of PAA after ligation and exclusion}

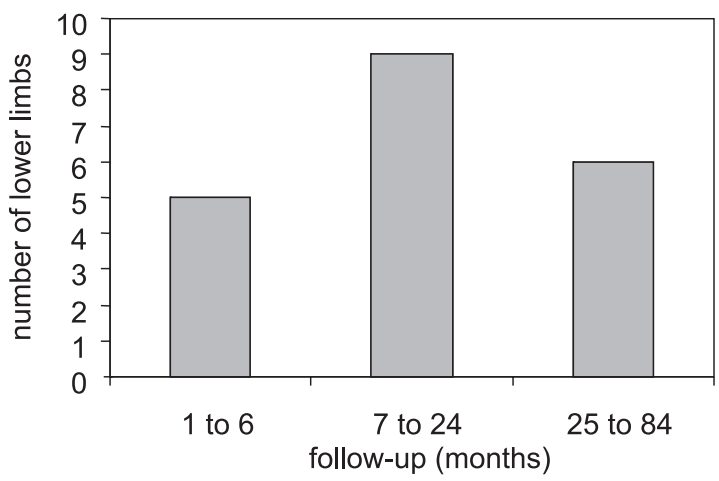

Figure 1 - Late ultrasonographic control of excluded popliteal artery aneurysms (PAA)

Twenty-seven patients underwent 34 primary popliteal aneurysm repair procedures. Preoperative measurements of the PAA were available for only 24 cases. Two patients had died, 1 had had a limb amputation, and 5 were lost to follow-up. Therefore, data of 16 patients and 20 PAA exclusion and bypass procedures were available for analysis. Table 1 shows patient characteristics and their aneurysms in this study.

\section{RESULTS}

Preoperative PAA diameters ranged from $1.3 \mathrm{~cm}$ to 6.1 $\mathrm{cm}($ mean $=3.1 \mathrm{~cm})$. Duplex ultrasound scanning was performed 1 month to 7 years after surgical repair (median = 11.5 months). The follow-up of patients revealed that of the 20 PAA, 10 had a decrease of 0.2 to $2.3 \mathrm{~cm}$ in mean
Table 1 - Patient characteristics and associated aneurysms in this study

\begin{tabular}{lll}
\hline & $\mathrm{N}$ & $\%$ \\
\hline $\begin{array}{l}\text { Patients } \\
\text { Male }\end{array}$ & 16 & 87.5 \\
$\quad$ Age at diagnosis & 14 & \\
$\quad$ Range & 43 to 86 years & \\
$\quad$ mean & 68.7 years & \\
Comorbidities & & 81.3 \\
$\quad$ Hypertension & 13 & 12.5 \\
Diabetes mellitus & 2 & 31.2 \\
Hyperlipidemia & 5 & 18.8 \\
Active smoker & 3 & 68.8 \\
Ex-smoker & 11 & 12.5 \\
CAD & 2 & 31.2 \\
Associated aneurysms & & 6.3 \\
abdominal aorta & 5 & 43.8 \\
femoral artery & 1 & 6.3 \\
contralateral PAA & 7 & \\
subclavian artery & 1 &
\end{tabular}

Observations: 7 patients had contralateral popliteal artery aneurysms (PAA), but 3 of them did not have preoperative measurements of popliteal diameter. Therefore, only 4 patients had the 2 lower limbs included in the study.

transverse diameter, 7 had an increase of $0.3 \mathrm{~cm}$ to $3.3 \mathrm{~cm}$, and 3 remained unchanged. Duplex ultrasound did not detect any intrasac flow in 15 PAA. However, in 5 cases flow was detected, $3(60 \%)$ of which exhibited increased diameters (Table 2). One patient with an enlarged aneurysm underwent limb amputation because of acute graft thrombosis. No other patient developed any symptoms, and the management adopted was duplex ultrasound scanning every 6 months or earlier if clinical changes were detected. One of these asymptomatic patients had a marked increase in diameter of $3 \mathrm{~cm}$, but this patient refused to undergo clinical and ultrasonographic evaluation and could only be contacted by phone.

\section{DISCUSSION}

The risk of thromboembolic events associated with PAA ranges from $18 \%$ to $31 \%,{ }^{2,4,9-12}$ whereas rupture is found in only $2 \%$ to $3 \%$ of most large series. ${ }^{10}$ Surgical treatment is the most effective method for preventing complications. However, no consensus about indications for surgery has been reached. Most authors suggest surgery for symptomatic patients with intermittent claudication, digital atheroembolism, rupture, critical ischemia by acute aneurysm thrombosis, or in cases of vein or nerve compression, or for asymptomatic patients with transverse diameters greater than $2.0 \mathrm{~cm}$. Intramural thrombi are associated with a higher risk of embolization and therefore are an indication for surgical repair. $2,3,9-11,13$ 
Table 2 - Diameter variation and intrasac flow detection by duplex scanning

\begin{tabular}{|c|c|c|c|c|c|}
\hline Name & $\begin{array}{l}\text { Preoperative } \\
\text { diameter }(\mathrm{cm})\end{array}$ & $\begin{array}{l}\text { Postoperative } \\
\text { diameter }(\mathrm{cm})\end{array}$ & Variation & Flow & $\begin{array}{l}\text { Length of postoperative } \\
\text { follow-up (months) }\end{array}$ \\
\hline \multirow[t]{2}{*}{$\mathrm{JZ}$} & R: 6.1 & 5.6 & -0.5 & Yes & 9 \\
\hline & L: 5.6 & 6.9 & 1.3 & Yes & 9 \\
\hline MA & 2.0 & 0.6 & -1.4 & No & 17 \\
\hline \multirow[t]{2}{*}{ MGO } & R: 2.5 & 2.3 & -0.2 & No & 5 \\
\hline & L: 1.8 & 1.6 & -0.2 & No & 5 \\
\hline PC & 1.3 & 4.6 & 3.3 & No & 3 \\
\hline JLM & 4.5 & 4.1 & -0.4 & No & 8 \\
\hline VG & 2.5 & 3.0 & 0.5 & No & 17 \\
\hline LM & 4.1 & 2.9 & -1.2 & No & 18 \\
\hline $\mathrm{AF}$ & 2.2 & 2.2 & 0 & No & 36 \\
\hline \multirow[t]{2}{*}{ WFS } & R: 2.8 & 2.8 & 0 & No & 13 \\
\hline & L: 2.4 & 2.2 & -0.2 & No & 30 \\
\hline DSO & 2.3 & 4.0 & 1.7 & No & 33 \\
\hline \multirow[t]{2}{*}{ AV } & R: 3.3 & 1.0 & -2.3 & No & 84 \\
\hline & L: 2.4 & 1.7 & -0.7 & No & 84 \\
\hline JPS & 4.5 & 4.2 & -0.3 & Yes & 9 \\
\hline HPL & 3.5 & 3.8 & 0.3 & No & 11 \\
\hline LMB & 2.6 & 2.6 & 0 & No & 1 \\
\hline $\mathrm{AP}$ & 1.6 & 1.9 & 0.3 & Yes & 12 \\
\hline ADR & 3.0 & 3.8 & 0.8 & Yes & 1 \\
\hline
\end{tabular}

$\mathrm{R}=$ right lower limb; $\mathrm{L}=$ left lower limb.

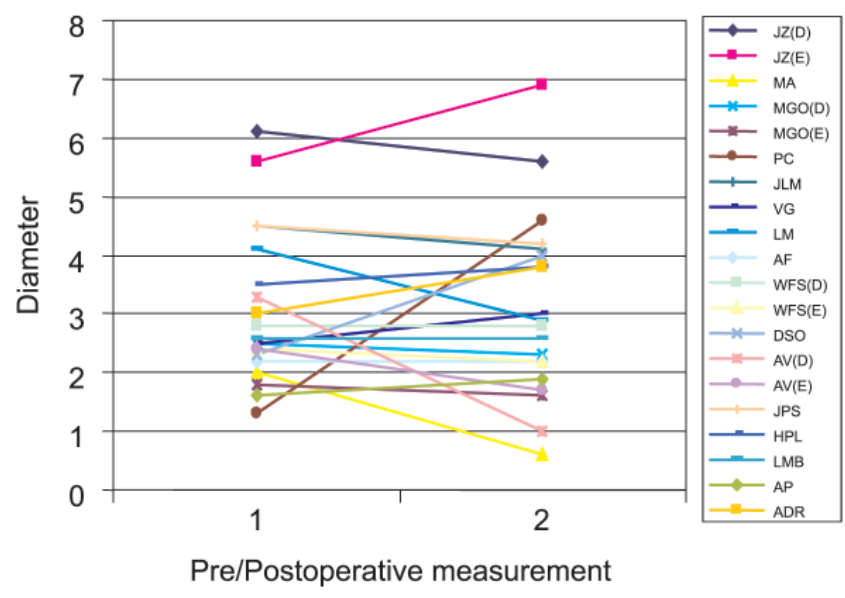

Figure 2 - Variation in aneurysmal sac diameter during postoperative followup

Surgical repair techniques have been described since ancient Greece. Antilllus, in 200 BC, reported an aneurysm ligation followed by packing of the sac. In 1785, Hunter, in England, and Desaut, in France, carried out a superficial femoral artery ligation in the adductor canal, the socalled Hunterian ligation. Matas, in 1885, developed the endoaneurysmorrhaphy technique, which lowered the limb amputation rate from $10.5 \%$ to $5.2 \% .{ }^{14-16}$ In 1969, Edwards ${ }^{7}$ proposed a surgical technique with minor trauma, and this has become the most common method of repair since then. ${ }^{3}$ The technique is an alternative to extensive exposure through the section of the tendons of the semimembranosus, gracilis, semitendinosus and sartorius muscles, and medial head of the gastrocnemius muscle, steps that are essential in the medial exposure of the popliteal artery, opening of the aneurysmal sac, ligation of collateral branches, and graft interposition.

The posterior approach, another alternative technique, ${ }^{15,16}$ is recommended for aneurysms confined to the popliteal fossa and that do not reach the Hunter hiatus superiorly. The aneurysm can be repaired by opening the sac and ligating collateral branches, avoiding the complications associated with the exclusion technique without resection of tendons. Endovascular repair has been recently described with immediate success but having high occlusion rates. Careful long-term follow-up and larger series should be studied to determine the durability of endoluminal stent grafts in comparison with traditional bypass surgery before its wide-scale use is recommended. ${ }^{17,18}$

Few studies report on PAA outcomes after exclusion and revascularization of the limb. Jones et $\mathrm{al}^{19}$ found that proximal and distal ligation adjacent to the PAA is more effective in isolating the aneurysm than long segment isolation, probably because of the large number of collateral branches filling the aneurysmal sac. They also observed that single proximal or distal ligation resulted in significant aneurysm growth. ${ }^{19}$

Ebaugh et $\mathrm{al}^{17}$ reviewed 25 cases of PAA treated with ligation and exclusion bypass grafting and reported 8 cases of enlargement of the postoperative diameter. They attributed these results to a phenomenon similar to type II endoleak or endotension after aortic endovascular repair due to flow from genicular branches. Kirkpatrick et $\mathrm{al}^{20}$ 
Table 3 - Comparison of patients that underwent ligation and exclusion of the aneurysmal sac

\begin{tabular}{|c|c|c|c|c|c|c|c|c|}
\hline Author & $\begin{array}{l}\text { No. } \\
\text { Patients }\end{array}$ & $\begin{array}{l}\text { No. } \\
\text { PAA }\end{array}$ & Male & $\begin{array}{l}\text { Age } \\
\text { (range) }\end{array}$ & $\begin{array}{l}\text { Increase in } \\
\text { Diameter }\end{array}$ & $\begin{array}{l}\text { Unchanged } \\
\text { diameter }\end{array}$ & $\begin{array}{l}\text { Reduction } \\
\text { in diameter }\end{array}$ & $\begin{array}{l}\text { Follow-up } \\
\text { length (range) }\end{array}$ \\
\hline Jones & 30 & 41 & 29 & 76 years $(67.3-84.7)$ & $12^{*}(33 \%)$ & 5 & 24 & 46 months $(4-88 \mathrm{~m})$ \\
\hline Ebaugh & 18 & 25 & 17 & 63 years $(42-80)$ & $8(32 \%)$ & $5(20 \%)$ & $12(48 \%)$ & \\
\hline \multirow[t]{3}{*}{ Kirkpatrick } & & 25 & & 72 years $(47-86)$ & 13 & 6 & 6 & 59 months $(1-120 \mathrm{~m})$ \\
\hline & Flow- & 13 & & & $5(38 \%)$ & 5 & 3 & \\
\hline & Flow+ & 12 & & & $8^{* * *}$ & 1 & 3 & \\
\hline \multirow[t]{3}{*}{ Wakassa } & 16 & 20 & 14 & 68.7 years $(43-86)$ & 7 & 3 & 10 & 11 months(1-84 m) \\
\hline & Flow- & 15 & & & $4(27 \%)$ & 3 & 8 & \\
\hline & Flow+ & 5 & & & $3^{* * *}$ & 0 & 2 & \\
\hline
\end{tabular}

* 1/4 of patients had compressive symptoms attributed to growth. ** 6 patients had symptoms associated with aneurysm, 1 patient had rupture of the popliteal artery aneurysm. $* * * 1$ patient had acute thrombosis of graft and underwent limb amputation. PAA $=$ popliteal artery aneurysm

studied patients with popliteal aneurysms who underwent ligation and bypass procedures and showed that one third had persistent flow in the aneurysm sac on late postoperative Doppler ultrasound scanning, and attributed this flow to patent genicular branches. Mehta et $\mathrm{al}^{21}$ and Battey ${ }^{22}$ reported finding intrasac flow and cases of rupture in excluded PAA, and they suggested opening of the aneurysmal sac and ligation of visible branches as the best technique for surgical repair. Flynn et $\mathrm{al}^{23}$ and Cinelli et $\mathrm{al}^{24}$ reported unusual complications of bypassed politeal aneurysms.

In this study, 7 of the 20 surgically repaired PAA (35\%) exhibited an increase in the transverse diameter. Intrasac flow may be explained by loose proximal or distal ligation or by reperfusion by collaterals. Growth without flow might have occurred because of pressurization of the excluded PAA by collaterals, or because of ligation failure. Table 3 compares our results with those reported by other authors, confirming that reperfusion of the aneurysmal sac does occur and should be a matter of concern. Patients in this study were all asymptomatic during follow-up.

\section{CONCLUSION}

Although the treatment of PAA by exclusion is widely accepted, the results found for this series of patients without rupture or compression, as well as results reported in the literature, show that patients who undergo aneurysm exclusion should be strictly followed up.
Wakassa TB, Matsunaga P, da Silva ES, Pinto CAV, Kauffman P, Aun R et al. Evolução do saco aneurismático após a exclusão cirúrgica dos aneurismas de artéria poplítea. Clinics. 2006;61(2): 107-12.

Os aneurismas da artéria poplítea são freqüentes e estão associados a eventos trombo-embólicos que podem acarretar isquemia grave com risco de perda da extremidade inferior acometida.

OBJETIVO: Avaliar a evolução clínica dos pacientes e ultra-sonográfica dos aneurismas de artéria poplítea excluídos pela técnica de Edwards.
MÉTODO: Análise retrospectiva dos pacientes com diagnóstico de aneurisma da artéria poplítea operados no Hospital das Clínicas da Faculdade de Medicina da Universidade de São Paulo, no período compreendido entre os anos de 1996 a 2004. Foram incluídos os pacientes submetidos à exclusão do aneurisma pela técnica de Edwards e que possuíam diâmetro transverso máximo do aneurisma mensurado no período pré e pós-operatório.

RESULTADOS: Dezesseis pacientes foram submetidos a correção cirúrgica de 20 aneurismas. O diâmetro do aneurisma no período pré-operatório variou entre $1,3 \mathrm{~cm}$ a $6,1 \mathrm{~cm}$ (média $3,1 \mathrm{~cm}$ ). O controle ultrasonográfico foi 
realizado em intervalo de 1 mês a 7 anos do procedimento cirúrgico. Houve diminuição do diâmetro do aneurisma de artéria poplítea em 10/20 extremidades (variação de 0,2 cm a 2,3 cm), aumento em 7/20 (variação de $0,3 \mathrm{~cm}$ a $3,3 \mathrm{~cm}$ ) e estabilidade em 3/20. Observou-se a ocorrência de fluxo no saco aneurismático em 5 dentre os 20 procedimentos. Destes, três apresentaram crescimento do mesmo (60\% dos casos com fluxo).
CONCLUSÃO: Esta amostra de pacientes, sem rotura ou sinais e sintomas de compressão, associada à análise da literatura, demonstra que o seguimento estreito do aneurisma excluído é necessário.

UNITERMOS: Aneurisma. Artéria poplítea. Controle pósoperatório.

\section{REFERENCES}

1. Dawson I, Su RB, van Bockel JH. Atherosclerotic popliteal aneurysm. Br J Surg. 1997;84:293-9.

2. Vermilion BD, Kimmins SA, Pace WG, Evans WE. A review of one hundred forty-seven popliteal aneurysms with long-term follow-up. Surgery. 1981;90:1009-14.

3. Varga ZA; Locke-Edmunds JC; Baird RN. A multicenter srudy of popliteal aneurysms. Joint Vascular Research Group. J Vasc Surg. 1994;20:171-7.

4. Dawson I, van Bockel H, Brand R, Terpstra JL. Popliteal artery aneurysm. Long-term follow-up of aneurysmal disease and results of surgical treatment. J Vasc Surg. 1991;13:398-47.

5. Drager LF, Silva HB, Bortolotto LA. Increased arterial distensibility and renovascular hypertension in Goldenhar syndrome. Clinics. 2005;60:173-176.

6. Wolosker N, Muraco Neto B, Munia MA, Rosoky RA, Ramos RS, Puech-Leão P. External aggression to the limb as a predictive factor in the evolution of patients undergoing arterial revascularization. Clinics. 2005;60(6):451-454.

7. Edwards WS. Exclusion and saphenous vein bypass of popliteal aneurysms. Surg Gynecol Obstet. 1969;128:829-30.

8. Azevedo FC, Zerati AE, Blasbalg R, Wolosker N, Puech-Leão P Comparison of ultrasonography, computed tomography and magnetic resonance imaging with intraoperative measurements in the evaluation of abdominal aortic aneurysms. Clinics. 2005;60:21-28.
9. Carpenter JP, Baker CF, Roberts B, Berkowitz HD, Lusk EJ, Perloff LJ. Popliteal artery aneurysms: current management and outcome. J Vasc Surg. 1994. 19:65-73

10 Kauffman P, Puech-Leão P. Surgical treatment of popliteal artery aneurysm: a 32-year experience. Braz Vasc J. 2002;1:3-12.

11. Duffy ST, Colgan MP, Sultan S, Moore DJ, Shanik GD. Popliteal aneurysms: a 10-year experience. Eur J Vasc Endovasc Surg. $1998 ; 16: 218-22$

12. Dijkstra B, Fleischl J, Knight D. Management and outcome of popliteal artery aneurysms in a New Zealand provincial centre. Aust N Z J Surg. 1998;68:255-7.

13. Bowrey DJ, Osmar H, Gibbons CP, Blackett RL. Atherosclerotic popliteal aneurysms: management and outcome in forty-six patients. Eur J Vasc Endovasc Surg. 2003;25:79-81.

14. Mahmood A, Salaman R, Sintler M, Smith SRG, Simms MH, Vohra RK. Surgery of popliteal artery aneurysms: a 12-year experience. J Vasc Surg. 2003;37:586-93.

15. Davidovic LB, Lotina SI, Kostic DM, Cinara IS, Cvetkovic SD, Markovic DM, et al. Popliteal artery aneurysms. World J Surg. 1998;22:812-17.

16. Ouriel K. The posterior approach to popliteal-crural bypass. J Vasc Surg. 1994;19:74-80.

17. Puech-Leão P, Kauffman P, Wolosker N, Anacleto AM. Endovascular grafting of a popliteal aneurysm using the saphenous vein. J Endovasc Surg. 1998;5:64-70. 
18. Tielliu IFJ, Verhoeven ELG, Zeebregts CJ, Prins TR, Span MM, Van den Dungen JJAM. Endovascular treatment of popliteal artery aneurysms: results of a prospective cohort study. J Vasc Surg. 2005;41:561-7.

19. Jones WT III, Hagio RT, Chiou AC, Decaprio JD, Franklin KS, Kashyap VS. Graft patency is not the only clinical predictor of sucess after exlcusion and bypass of popliteal artery aneurysms. J Vasc Surg. Feb 2003;37:392-8.

20. Kisrkpatrick UJ, McWilliams GR, Marti J, Brea JA, Gillig-Smith GL, Harris PL. Late complications after ligation and bypass for popliteal aneurysm. Br J Surg. 2004;91:174-7.
21. Mehta M, Champagne B, Darling III C, Roddy SP, Kreienberg PB, Ozsvath KJ, et al. Outcome of popliteal artery aneurysms after exclusion and bypass: significance of residual patent branches mimicking type II endoleaks. J Vasc Surg. 2004;40:886-90.

22. Battey PM, Skardasis GM, McKinnon WM. Ruptured of a previously bypassed popliteal aneurysm: a case report. J Vasc Surg. 1987;5:874-5.

23. Flynn JB, Nicholas GG. An unusual complication of bypassed popliteal aneurysms. Arch Surg. 1983;118:111-3.

24. Cinelli Jr. M, Kauffman P, Saciolotto R, Muraco B. Complicação rara da cirurgia do aneurisma da artéria poplítea: relato de caso e considerações sobre a técnica cirúrgica. Rev Ass Med Brasil. 1991;37:157-9. 